\title{
Genetic diversity of Sragen Black Cattle based on D-Loop gene sequencing analysis
}

\author{
Rahayu Kusumaningrum 1, 2, Sutopo ${ }^{1}$, Edy Kurnianto 1, * \\ ${ }^{1}$ Master of Animal Science, Faculty of Animal and Agricultural Sciences, Diponegoro University, Semarang, \\ 50275 \\ ${ }^{2}$ Livestok and Animal Health Services of Central Java Province, Tarubudaya-Ungaran, 50501 \\ *Correspondence: kurniantoedy17@gmail.com
}

Received: January 15 ${ }^{\text {th }}, 2020$; Accepted: March 6 ${ }^{\text {th }}, 2020$; Published online: July $7^{\text {th }}, 2020$

Abstrak

Tujuan: Penelitian bertujuan untuk mengkaji keragaman genetik Sapi Sragen (SASRA) berdasarkan sekuen gen D-loop.

Metode: Penelitian menggunakan 25 sampel darah SASRA yang tidak memiliki hubungan kekerabatan. DNA diekstraksi berdasarkan standar protokol menggunakan gSYNC DNA Mini Kit (Geneaid Biotech Ltd). Wilayah kontrol analisis urutan (D-loop) dalam DNA mitokondria (mtDNA) menggunakan primer spesifik forward: 5'- TAGTGCTAATACCAACGGCC-3' dan reverse: 5'AGGCATTTTGAGTGCCTTGC-3' dan kemudian disekuensing. Parameter yang diukur dalam penelitian ini adalah keragaman haplotipe, keragaman nukleotida dan jarak genetik. Penjajaran nukleotida dianalisis menggunakan program Molecular Evolutionary Genetics Analysis (MEGA) versi 6.0. untuk mendapatkan jarak genetik dan pohon filogeni. Keragaman haplotipe dan keragaman nukleotida dianalisis menggunakan program DNA Sequence Polymorphism (DNASP) v6.12.03.

Hasil: Hasil penelitian menunjukkan bahwa terdapat 11 haplotipe dengan $\mathrm{Pi}=0,00675 \pm 0,00201$ dan $\mathrm{Hd}=0,767 \pm 0,086$. Filogenetik SASRA terdiri dari dua kluster dengan rataan jarak genetik 0.0032 .

Kesimpulan: Disimpulkan bahwa semua SASRA berada pada kluster yang sama dan memiliki hubungan genetik yang lebih dekat dengan Bos indicus daripada Bos taurus dengan tingkat kemiripan berdasarkan BLAST sebesar 85,76\%.

Kata Kunci: Keragaman genetik; D-Loop; Sapi hitam Sragen

\section{Abstract}

Objective: The objective of this study was to investigate the genetic diversity of Sragen Black Cattle based on D-loop sequences analysis.

Methods: A total of 25 blood samples belonged to Sragen Black Cattle that had no genetic relationship within sample. The DNA genome was extracted based on the manufacturer's standard protocol using gSYNC DNA Mini Kit (Geneaid Biotech Ltd.). D-loop gene was amplified using specific primer forward: 5'- TAGTGCTAATACCAACGGCC-3' and reverse: 5'AGGCATTTTGAGTGCCTTGC-3' and then was sequenced. The sequencing result was aligned and analyzed by Molecular Evolutionary Genetics Analysis (MEGA) version 6.0 to reveal genetic distance and phylogenetic tree. Genetic diversity and haplotype were analysed by DNA Sequence Polymorphism (DnaSp) v6.12.03. 
Results: The results revealed that there were 11 haplotypes with $\mathrm{Pi}=0.00675 \pm 0.00201$ and $\mathrm{Hd}=$ $0.767 \pm 0.086$. Sragen Black Cattle was divided by two cluster in phylogenetic tree with average of genetic distance was 0.0032 .

Conclusions: In conclusion, all of Sragen Black Cattle are on the same cluster and have closer genetic relationship to Bos indicus rather than Bos taurus with similarity level $85.76 \%$ based on BLAST program.

Keywords: Genetic diversity; D-Loop; Sragen black cattle

\section{INTRODUCTION}

Sragen Black Cattle is a local cattle that is cultivated hereditary in Sragen Regency to fulfill animal protein consumption in Sragen society. As beef cattle, Sragen Black cattle has black to brownish color in almost over all its body (except around udder and vulva), smooth body hair, thin whip that stretched from navel to the end of the neck, no horn (both bull and cow), with small and short leg. A total 4.503 head of Sragen Black Cattle is distributed in Sragen Regency and raised by a semi-intensive animal farming system by local farmers, that is known by its adaptability to tropical conditions, ability to digest high fiber feed, good reproductive technical coefficient, good mothering ability, resistant against parasitic diseases and good carcass production [19]. Sragen Black Cattle has been reared by breeders for generations, but there is still very limited information on genetic diversity and its potential production which is one of the fundamental factors for determining the direction of breeding programs. As one of steps to prevent the depletion of Sragen Black Cattle, identification of genetic diversity and relationships within Sragen Black Cattle populations is needed in order to obtain genealogy information of the Sragen Black Cattle. Therefore, those informations are important to create a new livestock breed and to support policy development direction of its breeding program.

Based on previous researcher, molecular markers could be used to analyze genetic diversity in a species level. Mitochondrial DNA is one molecular marker that has been better characterized in most livestock and has been used for evolutionary studies. Mitochondrial DNA markers are described through $D$-loop chain DNA. The D-loop region in mitochondrial DNA has a higher rate of change compared to other mitochondrial DNA regions [20]. The use of mitochondrial DNA markers has been reported by several researchers to calculate genetic diversity of local cattle, among others were done in Aceh Cattle by D-Loop mtDNA analysis [1], Sragen Black Cattle, Pasundan and Pacitan Cattle by Cytochrome $b$ analysis [2], Turkish cattle by D-Loop mtDNA analysis [9] and Korean Black Cattle by Cytochrome $b$ analysis [6]. Analysis of using D-Loop mtDNA markers has never been done on Sragen Black Cattle, therefore the analysis of the distribution of haplotypes using mitochondrial DNA markers is important to do in the context of breeding, developing and utilizing Sragen Black Cattle as one of the local cattle in Indonesia. Thus, objective of this study was to investigate the genetic diversity of Sragen Black Cattle based on $D$-loop sequences analysis.

\section{MATERIALS AND METHODS}

\section{Samples collection}

A total of 25 blood samples belonged to Sragen Black Cattle were collected from Kedawung, Sambirejo, Karangmalang, and Plupuh sub-district, Central Java Province. Purposive sampling was used to determine the samples. Blood was taken using $3 \mathrm{cc}$ syringe through jugular venous that was firstly cleaned by using alcohol. The blood was then collected in vacutainers tubes with anticoagulant (EDTA), and then was stored in a cool box containing ice gel and transported to the laboratory for analysis. The DNA genome were extracted based on the manufacturer's standard protocol using gSYNC DNA mini kit (Geneaid Biotech Ltd.) for sequence analysis of D-loop in mitochondrial DNA (mtDNA). 


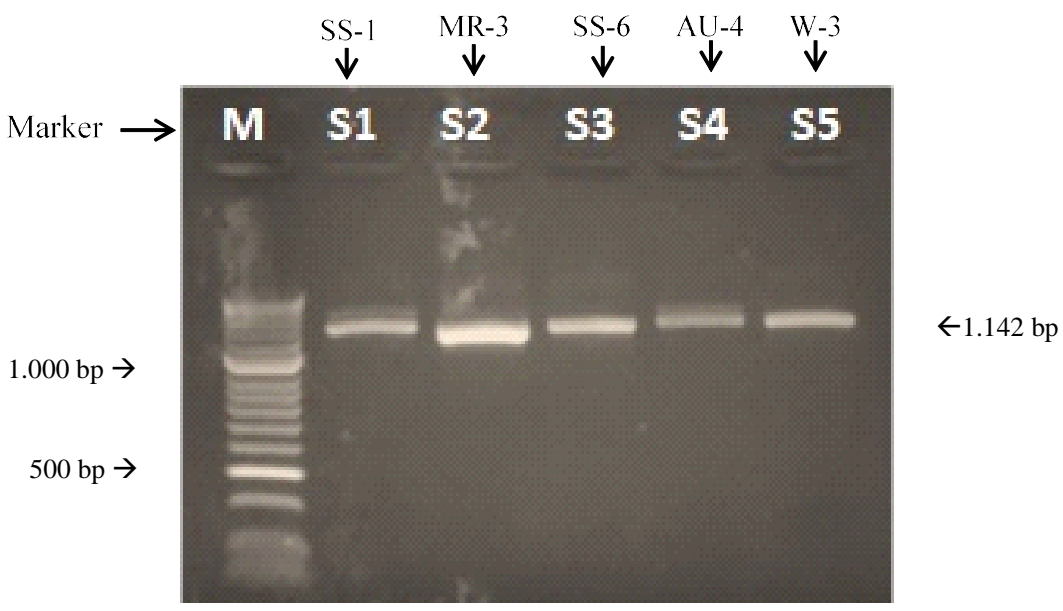

Figure 1. PCR product of D-loop of Sragen Black Cattle

\section{Polymerase chain reaction (PCR) and sequencing}

The D-loop mtDNA were amplified directly from the genomic DNA by Polymerase Chain Reaction (PCR). The primers used were primer forward: 5'-TAGTGCTAATACCAACGGCC-3' and reverse 5'-AGGCATTTTGAGTGCCTTGC-3' [14] that generated $1.142 \mathrm{bp}$ PCR product. Amplifications performed under the following conditions: pre-denaturation at $94^{\circ} \mathrm{C}$ for 5 minutes, followed by 30 cycles consisting of denaturation at $94^{\circ} \mathrm{C}$ for 45 seconds, annealing at $58^{\circ} \mathrm{C}$ for 1 minute, extension at $71^{\circ} \mathrm{C}$ for 1 minute and final extension at $71^{\circ} \mathrm{C}$ for 5 minutes. The products were electrophoresed and visualized in 1.5\% agarose gels that was stained using Ethidium Bromide then observed visually under Ultra Violet (UV) light and documented using a digital camera. The PCR product was then purified and sequenced by LPPT UGM sequencing service.

\section{Genetic diversity and genetic distance analysis}

A total of $1.142 \mathrm{bp}$ of $25 \mathrm{mtDNA}$ D-loop sequences were used to identify genetic diversity and genetic distance. Data were alignment and analyzed using Molecular Evolutionary Genetics Analysis (MEGA) version 6.0 [15]. The number of nucleotide variable sites $(\mathrm{V})$, singleton site $(\mathrm{S})$, parsimony site $(\mathrm{P})$, nucleotide diversity $(\mathrm{Pi})$, and haplotype diversity $(\mathrm{Hd})$ were calculated using DNA Sequence Polymorphism (DnaSP) version 6 [13].

\section{Haplotype analysis and phylogenetical relationships}

Number of haplotypes (NHap) and type of haplotype were calculated using DnaSP version 5.1 [13]. Phylogeny tree was constructed by Neighbor-Joining (NJ) using

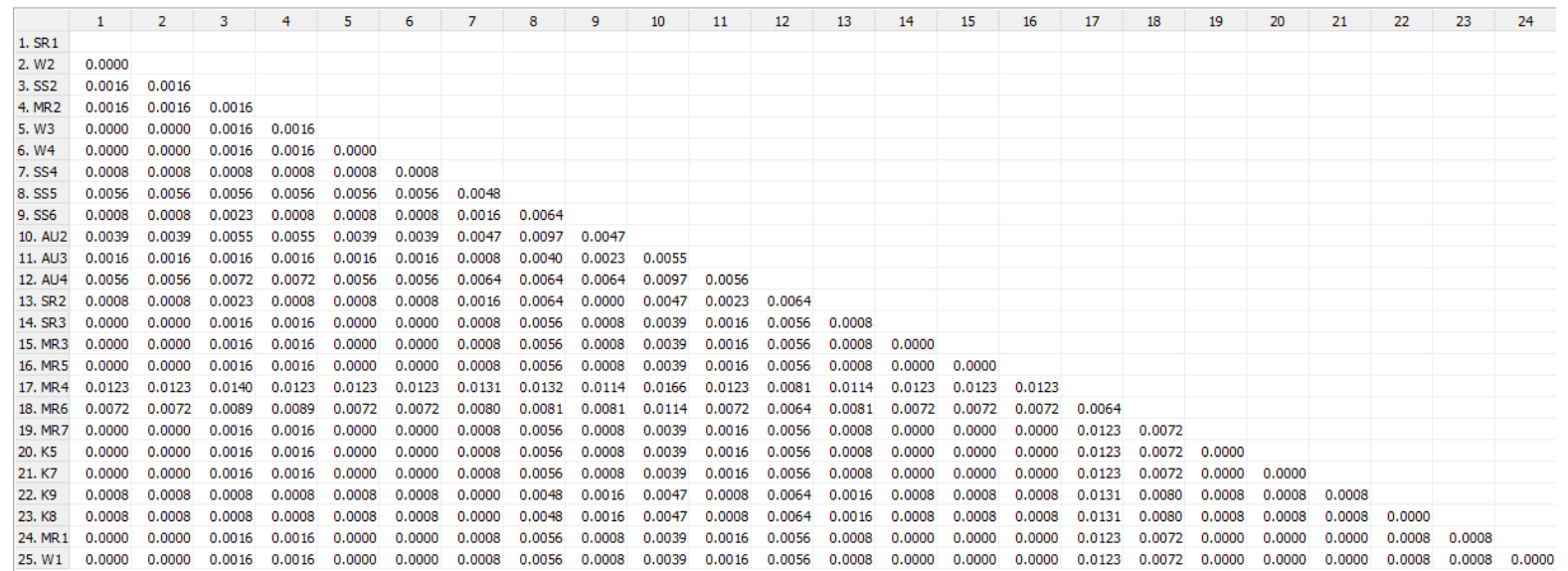

Figure 2. Genetic distance of Sragen Black Cattle 
MEGA version 6.0 [15] based on twenty-five sequences from this study and 6 sequences from genebank which were Bos indicus South China Cattle breed (EF524185), Bos indicus Nellore (AY126697.1), Bos indicus Ongole (AY378135.1), Bos indicus Sahiwal (L27732.1), Bos taurus North Eastern Asian Cattle breed (AB117092), Bos taurus Simmental (AF034442.1), Bos taurus Limousin (AF034446.1) and Bos taurus Angus (AY676858.1) and the similarity level check by Basic Local Alignment Search Tool (BLAST) program [22]. Phylogeny tree used to demonstrate genetic relationship of Sragen Black Cattle within population and as well as outgroup.

\section{RESULTS}

A total of $1.142 \mathrm{bp}$ of $25 \mathrm{mtDNA}$ D-loop sequences were obtained from Sragen Black Cattle (Figure 1). Furthermore, based on analysis, 11 haplotypes were observed in this study with $\mathrm{Pi}=0.00675 \pm 0.00201$ and $\mathrm{Hd}=$ $0.767 \pm 0.086$ that are shown in Table 1 .

While within population, diversity measures for total variable, singleton and parsimony site were 27,15 and 12 , respectively. Singleton and parsimony sites positions were presented in Table 2. Results

Table 1. Different base nucleotide on mtDNA D-loop in Sragen Black Cattle

\begin{tabular}{|c|c|c|c|c|c|c|c|c|c|c|c|c|c|c|c|c|c|c|c|c|c|c|c|c|c|c|c|c|}
\hline \multirow{4}{*}{ No } & \multirow{3}{*}{$\begin{array}{l}\text { Sample/ } \\
\text { Type of }\end{array}$} & \multicolumn{27}{|c|}{ Site base nucleotide number- } \\
\hline & & 1 & & 2 & 2 & 2 & 2 & 2 & 2 & 2 & 2 & 2 & 3 & 3 & 3 & 3 & 3 & 3 & 3 & 3 & 3 & 4 & 4 & 4 & 4 & 4 & 4 & 5 \\
\hline & & 0 & 5 & 1 & 1 & 3 & 6 & 7 & 7 & 8 & 8 & 9 & 1 & 1 & 3 & 3 & 4 & 5 & 5 & 7 & 7 & 2 & 2 & 4 & 7 & 8 & 8 & 2 \\
\hline & & 4 & 1 & 2 & 3 & 8 & 0 & 4 & 5 & 2 & 7 & 5 & 2 & 3 & 4 & 5 & 7 & 6 & 7 & 8 & 9 & 2 & 6 & 7 & 6 & 2 & 4 & 5 \\
\hline 1 & SR1/H-1 & A & $\mathrm{T}$ & A & G & $\mathrm{T}$ & $\mathrm{T}$ & $\mathrm{T}$ & A & A & A & A & $\mathrm{T}$ & $\mathrm{A}$ & $\mathrm{T}$ & A & A & A & $\mathrm{T}$ & G & $\mathrm{C}$ & $\mathrm{T}$ & C & A & G & G & G & G \\
\hline 2 & SR3/H-1 & . & . & . & . & . & $\cdot$ & . & . & . & . & . & . & & . & . & . & . & . & . & . & . & . & . & . & . & . & . \\
\hline 3 & W1/H-1 & . & . & . & . & . & . & . & . & . & . & . & . & . & . & . & . & . & . & . & . & . & $\cdot$ & . & . & . & . & . \\
\hline 4 & W2/H-1 & $\cdot$ & . & . & . & . & 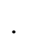 & . & . & . & . & . & . & . & . & . & . & . & . & . & . & . & . & . & . & . & . & . \\
\hline 5 & W3/H-1 & . & . & . & . & . & . & . & . & . & . & . & . & . & . & . & . & . & . & . & . & . & • & . & . & $\cdot$ & . & . \\
\hline 6 & W4/H-1 & . & . & . & . & . & . & . & . & . & . & . & . & . & . & . & . & . & . & . & . & . & · & . & . & $\cdot$ & . & . \\
\hline 7 & MR1/H-1 & . & . & . & . & . & . & . & . & . & . & . & . & . & . & . & . & . & . & . & . & . & . & . & . & . & . & . \\
\hline 8 & MR3/H-1 & . & . & . & . & . & . & . & . & . & . & . & . & . & . & . & . & . & . & . & . & . & . & . & . & . & . & . \\
\hline 9 & MR5/H-1 & . & . & . & . & . & ${ }^{\circ}$ & . & . & . & . & . & . & . & . & . & - & . & . & . & . & . & r & . & . & . & . & . \\
\hline 10 & MR7/H-1 & . & . & . & . & . & . & . & . & . & . & . & . & . & . & . & . & . & . & . & . & . & & . & . & . & . & . \\
\hline 11 & $\mathrm{~K} 5 / \mathrm{H}-1$ & . & . & . & . & . & ${ }^{\circ}$ & . & . & . & . & . & . & . & . & . & . & . & . & . & . & . & . & . & . & . & . & . \\
\hline 12 & $\mathrm{~K} 7 / \mathrm{H}-1$ & . & . & . & . & . & . & . & . & . & . & . & . & . & . & . & . & . & . & . & . & . & . & . & . & . & . & . \\
\hline 13 & $\mathrm{SS} 2 / \mathrm{H}-2$ & G & . & . & . & . & . & . & . & . & . & . & . & . & . & . & G & . & . & . & . & . & . & . & . & . & . & . \\
\hline 14 & MR2/H-3 & . & . & . & . & . & . & . & . & . & . & . & . & . & . & . & G & . & . & . & . & . & $\mathrm{T}$ & . & . & $\cdot$ & . & . \\
\hline 15 & SS4/H-4 & . & . & . & . & . & . & . & . & . & . & . & . & . & . & . & G & . & . & . & . & . & & . & $\cdot$ & $x^{\prime}$ & . & . \\
\hline 16 & K9/H-4 & . & . & . & . & . & . & . & . & . & . & . & . & . & . & . & G & . & . & . & . & . & & . & . & . & . & . \\
\hline 17 & K8/H-4 & . & . & . & . & . & . & . & . & . & . & . & . & . & . & . & G & . & . & . & . & . & • & . & . & . & . & . \\
\hline 18 & SS5/H-5 & . & $\cdot$ & $\cdot$ & . & . & . & . & . & . & $\mathrm{C}$ & . & . & G & . & G & G & . & . & $\mathrm{T}$ & G & G & $\cdot$ & . & . & $\cdot$ & . & . \\
\hline 19 & SS6/H-6 & . & $\cdot$ & . & . & . & . & . & . & . & . & . & . & . & . & . & . & . & . & . & . & . & $\mathrm{T}$ & . & $\cdot$ & . & . & . \\
\hline 20 & SR2/H-6 & $\cdot$ & $\cdot$ & $\cdot$ & . & . & . & . & . & $\cdot$ & . & . & . & - & . & . & ${ }^{\circ}$ & . & . & . & . & . & $\mathrm{T}$ & . & . & . & . & . \\
\hline 21 & AU2/H-7 & . & . & . & . & . & . & . & . & G & . & G & G & . & G & . & . & G & . & . & . & . & & . & . & . & . & . \\
\hline 22 & AU3/H-8 & . & . & . & . & . & . & . & . & - & . & . & . & G & . & . & G & . & . & . & . & . & . & . & . & . & . & . \\
\hline 23 & AU4/H-9 & . & . & . & . & . & C & . & . & . & $\mathrm{C}$ & . & . & G & . & G & $\cdot$ & . & . & . & . & . & . & $\mathrm{T}$ & $\mathrm{T}$ & . & . & $\mathrm{C}$ \\
\hline 24 & MR4/H-10 & . & A & $\mathrm{T}$ & $\mathrm{T}$ & A & C & $\mathrm{C}$ & $\mathrm{C}$ & . & $\mathrm{C}$ & . & . & G & . & G & r & . & G & . & . & . & $\mathrm{T}$ & . & $\mathrm{T}$ & $\mathrm{C}$ & . & $\mathrm{C}$ \\
\hline 25 & MR6/H-11 & . & . & $\mathrm{T}$ & $\mathrm{T}$ & . & . & . & . & . & C & & . & G & 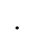 & G & & - & G & . & . & . & & 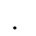 & . & C & $\mathrm{T}$ & C \\
\hline
\end{tabular}




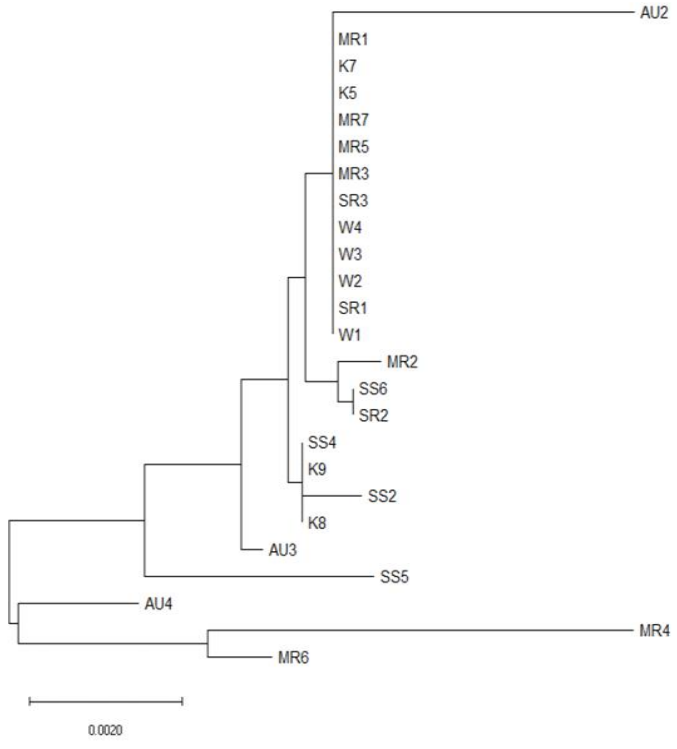

Figure 3. Phylogenetic tree of Sragen Black Cattle

showed that average of genetic distance within samples was 0.0032 (Figure 2).

Based on the analysis of genetic differences within population, phylogeny trees was formed based on the Kimura 2 parameter method with 1000 times repetition bootstrap test. Result was obtained 2 clusters of Sragen Black Cattle, namely A Cluster and B Cluster (Figure 3). The Neighbor-Joining construction phylogeny tree showed that sample were randomly scattered in the same cluster together and has a closer genetic relationship to Bos indicus rather than Bos taurus with similarity level as much as $85,76 \%$ based on BLAST program (Figure 4).

\section{DISCUSSION}

\section{Haplotype diversity}

Based on haplotype analysis, the result was different compared to another local cattle. Bali cattle have two haplotypes with one polymorphic site [16]. Genetic diversity (Pi) value in this study was in medium category while haplotype diversity (Hd) value was in high category. According to Nei [21], genetic diversity (Pi) value ranged from 0.001 to 0.01 and defined into 3 categories i.e., high category ranged from 0.08 to 0.1 , medium category ranged from 0.05 to 0.07 , and low category ranged from 0.01 to 0.04 . Meanwhile, haplotype diversity value (Hd) in range $\geq 0<0.5$ was included in low category, while $\mathrm{Hd}$ value in range $>0,5 \leq 1$ was included in high category. High haplotype diversity will be followed by high genetic diversity as well and vice versa. Haplotype diversity and nucleotide diversity of mtDNA are two important indicators for assessing population polymorphism and genetic differentiation [11-12]. Liu et al. [7] and Liu et al. [8] revealed that a high population diversity showed by a high value of haplotype diversity and nucleotide diversity of mtDNA. Low genetic diversity indicated the presence of inbreeding. Fu's Fs statistic in this study showed negative value (-1.766). It indicated that Sragen Black Cattle was experienced inbreeding. A negative value of Fu's Fs indicated an excessive number of alleles due to population constraints on selection tah are too dominan [3]. Moreover, it was clarified by the fact that nucleotide characteristics information in this study were 95.36\% conserved (Table 2). Conserved region is an area that was not experience mutation. The more the conserved region on sequences, the less the genetic variation will be [17].

\section{Genetic distance}

Result of this study showed the basic population that used for breeding program of Sragen Black Cattle was came from the same ancestor (Figure 3). This condition is caused by the random animal mating (uncontrolled mating) which is often conducted by tran-

Table 2. Nucleotide characteristics on mtDNA D-loop in Sragen Black Cattle

\begin{tabular}{|c|c|c|}
\hline $\begin{array}{l}\text { Nucleotide } \\
\text { characteristics }\end{array}$ & $\begin{array}{l}\text { Sragen black } \\
\text { catlle }\end{array}$ & Site position \\
\hline Conserve $(\%)$ & $556(95.36 \%)$ & - \\
\hline Variabel (\%) & $27 \quad(4.63 \%)$ & - \\
\hline Parsimony & 12 & 212213260287313335347357426476482525 \\
\hline Singleton & 15 & 104151238274275282295312334356378379422447484 \\
\hline
\end{tabular}




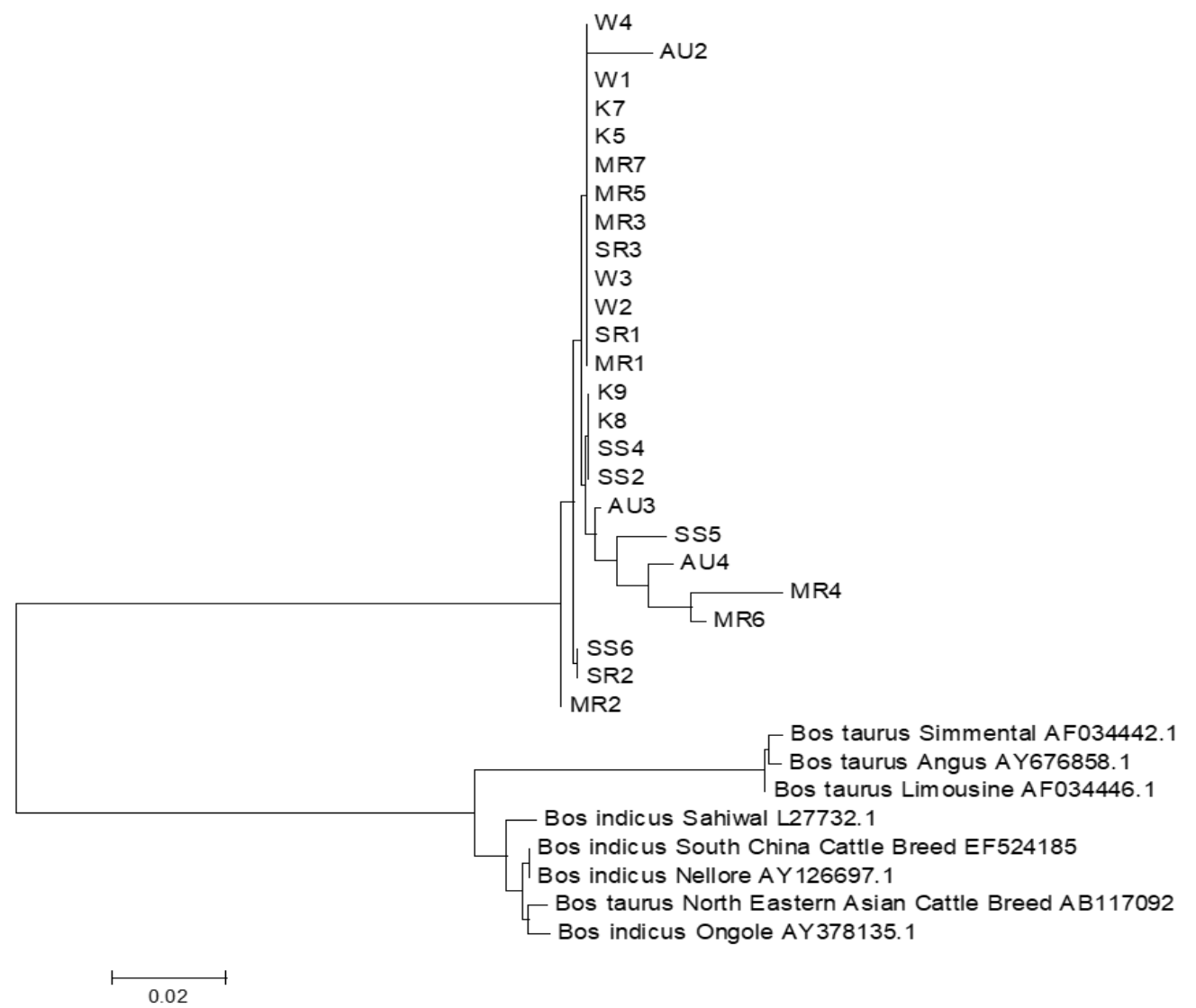

Figure 4. Phylogenetic tree of Sragen Black Cattle with Bos indicus and Bos iaurus on genbank

ditional farmers. Inbreeding will lead to a depression of life and reproduction [5]. The potency of inbreeding will continue in the event of random mating among animals that already has extremely close genetic distance. This condition may lead to the depression of biological fitness (inbreeding depression) such as homozygous individuals, mutation defects from bottlenecks effects, recessive alleles, and imbalances of gene flow $[4,17]$.

The calculation results of the genetic distance between individuals in 25 heads of Sragen Black Cattle were from 0.0000 to 0.0166 . The highest genetic distance in this study were between MR4 and AU2 (0.0166); MR4 and SS2 (0.0140); MR4 and SS5 (0.0132). While the lowest genetic distance within samples (0.0000) was found in cattle which were had the same type of haplotype (type 1 , 4 and 6). The close genetic distance was caused by the least differences of nucleotide bases [10]. Petersen et al [12] stated that genetic diversity is influenced by the distribution of animal's breed in certain population and historic records regarding paternal and maternal breeding patterns, and the presence of crossbreeding. The low population and selection patterns will affect heterozygosity condition which is reflected on phenotypic diversity.

\section{CONCLUSION}

All of Sragen Black Cattle has a genetic relationship with the same ancestor and is closer to Bos indicus than Bos taurus. Based on genetic diversity value of Sragen Black Cattle population in this study suggests an efforts to preserve Sragen Black Cattle as one of animal genetic resource in Indonesia.

\section{CONFLICT OF INTEREST}

The authors declare no conflict of interest with any financial organization regarding the material discussed in the manuscript.

\section{ACKNOWLEDGMENTS}

Thanks to Dinas Peternakan dan Kesehatan Hewan Provinsi Jawa Tengah and Dinas Peternakan dan Perikanan Kabupaten 
Sragen for allowing and helping to collect sample in this research.

\section{REFERENCES}

1. Abdullah, M. A. N. 2008. Hubungan kekerabatan sapi Aceh dengan menggunakan daerah displacement-loop. Agripet. 8:9-14. doi:10.17969/agripet.v8i2.609.

2. Adinata, Y., T. Hartatik, and D. N. H. Hariyono. 2019. Genetic diversity and phylogenetic analysis of two Indonesian local cattle breeds based on Cytochrome $b$ gene sequences. Biodiversitas. 20:17-22. doi:10.13057/biodiv/d200103.

3. Ashfaq, M., P. D. N. Hebert, M. S. Mirza, A. M. Khan, S. Mansoor, G. S. Shah, and Y. Zafar. 2014. DNA barcoding of bemisia tabaci complex (hemiptera: aleyrodidae) reveals southerly expansion of the dominant whitefly species on cotton in Pakistan. PloS One. 9:1-14. doi:10.1371/journal.pone.0104485.

4. Charlesworth, D. and J. H. Willis. 2009. The genetics of in-breeding depression. Nat. Rev. Genet. 10:783-796. doi:10.1038/nrg2664.

5. Hidayat, T. and A. Pancoro. 2008. Kajian filogenetika molekuler dan peranannya dalam menyediakan informasi dasar untuk meningkatkan kualitas sumber genetik anggrek. Jurnal AgroBiogen. 4:35-40. doi:124.81.126.59/handle/123456789/7696.

6. Kim, J. H., M. B. Byun, M. J. Kim, S. W. Suh, Y. S. Kim, Y. G. Ko, S. W. Kim, K. S. Jung, D. H. Kim, and S. B. Choi. 2013. Phylogenetic analysis of Korean Black Cattle based on the mitochondrial cytochrome b gene. Life Sci. 23:24-30. doi:10.5352/JLS.2013.23.1.24.

7. Liu, R. Y., L. Chu-Zhao, and Y. Gong-She. 2007. Genetic diversity and origin of Chinese domestic goats revealed by complete mtDNA D-loop sequence variation. Asian-Australas. J. Anim. Sci. 20:178-183. doi:10.5713/ajas.2007.178 .

8. Liu, R. Y., L. Chu-Zhao, and Y. Gong-She. 2006. The genetic di-vversity of mtDNA D-loop and origin of Chinese goats. Acta
Genet. Sinica. 33:420-428. doi:10.1016/S0379-4172(06)60069-3.

9. Ozdemir, M. and D. Unsal. 2009. Determination of phylogenetic relationships of Turkish Native Cattle Breeds with Other Cattle Breeds using mitochondrial dna d-loop sequence polymorphism. Asian-Austral. J. Anim. Sci. 22:955-961. doi:10.5713/ajas.2009.70549.

10. Pekkala, N., K. E. Knott, J. S. Kotoaho, and M. Puurtinen. 2014. The effect of inbreeding rate on fitness, inbreeding depression and heterosis over a range of in-breeding coefficients. Evol. Appl. 7:1107-1119. doi:10.1111/eva.12145.

11. Pereira, F., L. Pereira, B. Van Asch, D.G. Bradley, and A. Amorim. 2005. The mtDNA catalogue of all Portuguese autochthonous goat (Capra hircus) breeds: high diversity of female lineages at the western fringe of European distribution. Mol. 14:2313-2318. doi:10.1111/j.1365-294X.2005.02594.x.

12. Petersen, J. L., J. R. Mickelson, E. G. Cothran, L. S. Andersson, J. Axelsson, E. Bailey and D. Bannasch. 2013. Genetic diversity in the modern horse illustrated from genome-wide snp data. PloS One. 8:e54997. doi:10.1371/journal.pone.0054997.

13. Rozas, J., A. Ferrer-Mata, J.C. Sánches-Delbarrio, S. Girao-Rico, P. Librado, S.E. Ramos-Onsins, and A. Sánchez-Gracia. 2017. DnaSP 6: DNA sequence polymorphism analysis of large datasets. Mol. Biol. Evol. 34:3299-3302. doi:10.1093/molbev/msx248.

14. Suzuki, R., S. J. Kemp, and A. J. Teale. 1993. Polymerase chain reaction analysis of mitochondrial DNA polymorphism in N'Dama and Zebu cattle. Anim. Genet. 24:339-343. doi:10.1111/j.1365-2052.1993.tb00337.x.

15. Tamura, K., G. Stecher, D. Peterson, A. Filipski, and S. Kumar. 2013. MEGA6: Molecular evolutionary genetics analysis version 6.0. Mol. Biol. Evol. 30:2725-2729. doi:10.1093/molbev/mst197.

16. Wisesa, A. A. N. G. D., T. G. O. Pemayun, and I. G. K. N. Mahardika. 2012. Analisis 
sekuens D-loop DNA mitokondria sapi Bali dan banteng dibandingkan dengan bangsa sapi lain di dunia. Indonesia Medicus Veterinus. 1:281-292.

17. Wright, L. I., T. Tragenza, and D. J. Hosken. 2008. Inbreeding, inbreeding depression and extinction. Conserv. Genet. 9:833-834. doi:10.1007/s10592-007-9405-0.

18. Zhao, Y., J. Zhang, E. Zhao, X. Zhang, X. Liu, and N. Zhang. 2011. Mitochondrial DNA diversity and origins of domestic goats in Southwest China (excluding Tibet). Small Ruminant Res. 95:40-47. doi:10.1016/j.smallrumres.2010.09.004.

19. Dinas Peternakan dan Perikanan Kabupaten Sragen. 2016. Grand design pengembangan perbibitan sapi Sragen. Dinas Peternakan dan Perikanan Kabupaten Sragen, Sragen.

20. Muladno. 2006. Aplikasi teknologi molekuler dalam upaya peningkatan produktivitas hewan. pelatihan teknik diagnostik molekuler untuk peningkatan produksi peternakan dan perikanan di Kawasan Timur Indonesia. Kerjasama Pusat Studi Ilmu Hayati, Lembaga Penelitian dan Pemberdayaan Masyarakat Institut Pertanian Bogor dan Direktorat Jenderal Pendidikan Tinggi Depdiknas, Bogor.

21. Nei, M. and S. Kumar. 2000. Molecular evolution and phylogenetics. Oxford University Press, New York.

22. NCBI. National central biological information: Basic local alignment tools. [cited 2019 Oct 25] Available from: https://blast.ncbi.nlm.nih.gov/Blast.cgi. 